\title{
Bridging autoinflammatory and autoimmune diseases
}

\author{
Emad M. El-Shebiny', Enas S. Zahran', Sabry A. Shoeib ${ }^{1}$ and Eman S. Habib ${ }^{2^{*}}$ (D)
}

\begin{abstract}
Background: Autoimmunity is used to cause by impairment of adaptive immunity alone, whereas autoinflammatory was originally defined as a consequence of unregulated innate immunity. So, the pathogenetic mechanisms of autoimmune diseases were well-thought-out to be mediated by B and T lymphocytes. Whereas, autoinflammatory diseases were defined as unprovoked times of inflammation with the absence of a high titre of autoantibodies.

Main body of the abstract: Autoimmune and autoinflammatory diseases were split into two groups, but considering the similarities, it can be considered as only one group of diseases with a large immune pathological and clinical spectrum which involves at one end pure autoimmune diseases and the other pure autoinflammatory diseases.

Conclusions: We can safely conclude that there is bridging between autoinflammatory and autoimmune diseases.

Keywords: Autoinflammatory, Autoimmune diseases, Bridging
\end{abstract}

\section{Background}

Autoinflammatory diseases are a novel and growing group of self-directed inflammatory disorders, not only described as episodic fever syndrome but also with periods of acute inexpressible inflammation involving the innate immune system [1]. They are characterized by inflammatory episodes at disease-prone sites, in the absence of autoreactive $\mathrm{T}$ cells and elevation of autoantibody level [2].

Autoimmune diseases are defined as an impairment of the immune system result in loss of immune tolerance against self-tissues, by the existence of autoreactive $\mathrm{T}$ and B cells, and by a complex mechanism of multifactorial etiology, whereas genetics and environmental factors are responsible for the onset of disease. Autoimmune disorders may be systemic, as in the case of systemic lupus erythematosus, or tissue-specific, as in the case of multiple sclerosis (against myelin) or type 1 diabetes (against pancreatic beta cells) [3].

\footnotetext{
* Correspondence: emanet.habib@gmail.com

${ }^{2}$ Research Committee, Faulty of Medicine, Menoufia University, Shebin

El-Kom, Egypt

Full list of author information is available at the end of the article
}

Autoinflammatory and autoimmune diseases result from abnormal changes in innate and adaptive immunity that may result in the primary inflammatory state to an organ-specific injury. These disorders have heterogeneity in to affected organs and clinical phenotypes. But despite the variances in etiology and phenotypic changes, they share genetic basis, clinical presentation, and treatment results. The mechanisms of initiation remain poorly understood; however, the presence of similarities between autoimmune and autoinflammatory disorders designates variable degrees of interaction between them [4].

Autoimmune and autoinflammatory disorders are divided into two groups, but if similarities are taken into consideration, they might be considered as one group of diseases with a large immune pathological and clinical spectrum which contains at one end pure autoimmune diseases and the other pure autoinflammatory diseases. Despite the variances in primary players, autoinflammatory diseases share common features with autoimmune diseases, such as self-tissue-directed inflammation without observable infectious trigger or injury. While in autoinflammatory diseases the innate immunity directly results in tissue inflammation, in autoimmune disease

\section{Springer Open}

(c) The Author(s). 2021 Open Access This article is licensed under a Creative Commons Attribution 4.0 International License, which permits use, sharing, adaptation, distribution and reproduction in any medium or format, as long as you give appropriate credit to the original author(s) and the source, provide a link to the Creative Commons licence, and indicate if changes were made. The images or other third party material in this article are included in the article's Creative Commons licence, unless indicated otherwise in a credit line to the material. If material is not included in the article's Creative Commons licence and your intended use is not permitted by statutory regulation or exceeds the permitted use, you will need to obtain permission directly from the copyright holder. To view a copy of this licence, visit http://creativecommons.org/licenses/by/4.0/. 
the innate immune system triggers the adaptive system, and this activates the inflammatory process [5].

\section{Main text}

\section{Autoinflammatory diseases}

Autoinflammatory diseases are a group of monogenic and multifactorial (polygenic) disorders characterized by frequent inflammatory episodes whose heterogeneous symptoms are recurrently associated with fever (Tables 1 and 2). The important pathogenetic mechanism in autoinflammatory diseases is the direct and indirect dysregulation of inflammasomes; the multiprotein cytoplasmic complexes are relevant to innate immunity and inflammatory responses. The main components of inflammasomes are members of the nucleotide-binding oligomerization domain (NOD)-like receptor (NLR) family, a class of pattern recognition receptors. When activated by pro-inflammatory triggers such as the stimuli transmitted by pathogens or damaged cells, NLRs detect pathogen-associated or damage-associated molecular patterns and begin inflammasome assembly, which induces the proteolytic activation of caspases and turning of pro-interleukin (IL)-1 into active (IL)-1, a key molecule of inflammation and innate immunity [6].

\section{Autoimmune diseases}

The term "autoimmunity" is common to be referred to as a state associated with the impairment of adaptive immunity alone. So, the pathogenesis of autoimmune diseases was exclusively mediated by $\mathrm{B}$ and $\mathrm{T}$ lymphocytes whose $B$ and $T$ cell receptors recognized specific antigens, started the inflammatory response against autoantigens, and activated B cell-mediated autoantibody production [8].

The existence of autoantibodies is a common character of autoimmune diseases, and a big number of serum antibodies are guided against functional structures of the cell (nucleic acids, nuclear molecules, receptors, or other functional cell components). They not only play an important role in diagnosis and classification but may also be tangled in tissue damage. One of the best well-known pathogenic effects of autoantibodies is the cytotoxic damage of cells by cell surface binding and lysis. In this process, complement activation and/or antibody dependent cell-mediated cytotoxicity are the most common pathways

Table 1 Summary of monogenic autoinflammatory diseases [7]

\begin{tabular}{|c|c|c|c|}
\hline $\begin{array}{l}\text { Monogenic auto } \\
\text { inflammatory diseases }\end{array}$ & $\begin{array}{l}\text { Mode of inheritance/ } \\
\text { gene (protein) }\end{array}$ & Main clinical features & Treatment \\
\hline $\begin{array}{l}\text { Familial Mediterranean } \\
\text { fever }\end{array}$ & $\begin{array}{l}\text { Recessive } \\
\text { MEFV (Pyrin) }\end{array}$ & $\begin{array}{l}\text { Recurrent fever (12-72) h, arthritis, and serositis } \\
\text { (abdominal pain and thoracic pain) }\end{array}$ & $\begin{array}{l}\text { Colchicine (IL-1 blockade in refractory } \\
\text { cases or colchicine side-effects) }\end{array}$ \\
\hline $\begin{array}{l}\text { TNF receptor-associated } \\
\text { periodic syndrome }\end{array}$ & $\begin{array}{l}\text { Dominant } \\
\text { TNFRSF1A (TNFR1) }\end{array}$ & $\begin{array}{l}\text { Recurrent fever (1-3) weeks arthromyalgia, } \\
\text { fasciitis, rash, conjunctivitis periorbital edema, } \\
\text { and splenomegaly }\end{array}$ & $\begin{array}{l}\text { IL-1 blockade Corticosteroids/ } \\
\text { Etanercept/NSAID/Colchicine }\end{array}$ \\
\hline $\begin{array}{l}\text { Hyperimmunoglobulinemia } \\
\text { with periodic fever } \\
\text { syndrome }\end{array}$ & $\begin{array}{l}\text { Recessive } \\
\text { (Mevalonate Kinase gene) }\end{array}$ & $\begin{array}{l}\text { Recurrent fever(3-7) days, abdominal pain, } \\
\text { diarrhea, hepato-splenomegaly, and } \\
\text { lymphadenopathy }\end{array}$ & $\begin{array}{l}\text { IL-1 blockade/NSAID Corticosteroids/ } \\
\text { TNF blockade }\end{array}$ \\
\hline $\begin{array}{l}\text { Familial cold auto } \\
\text { inflammatory syndrome }\end{array}$ & $\begin{array}{l}\text { Dominant } \\
\text { NLRP3 } \\
\text { (Cryopyrin) }\end{array}$ & $\begin{array}{l}\text { Recurrent fever ( } 12 \text { h-2 days), and } \\
\text { cold-induced urticaria-like rash, conjunctivitis, } \\
\text { and arthralgia }\end{array}$ & IL-1 blockade \\
\hline Muckle-Wells syndrome & $\begin{array}{l}\text { Dominant } \\
\text { NLRP3 }\end{array}$ & $\begin{array}{l}\text { Recurrent fever (2-3) days if present, urticaria } \\
\text { rash, and sensori-neuronal deafness }\end{array}$ & IL-1 blockade \\
\hline $\begin{array}{l}\text { Neonatal onset multi } \\
\text { systemic inflammatory } \\
\text { disorder }\end{array}$ & $\begin{array}{l}\text { Dominant } \\
\text { NLRP3 }\end{array}$ & $\begin{array}{l}\text { Subcontinuous fever, rash, neurologic symptoms, } \\
\text { and skeletal abnormalities }\end{array}$ & IL-1 blockade \\
\hline $\begin{array}{l}\text { Pyogenic arthritis } \\
\text { pyoderma gangrenosum } \\
\text { and acne syndrome }\end{array}$ & $\begin{array}{l}\text { Dominant } \\
\text { (PSTPIP1) }\end{array}$ & $\begin{array}{l}\text { Pyoderma gangrenosum, cystic acne, and } \\
\text { sterile pyogenic oligoarthritis }\end{array}$ & $\begin{array}{l}\text { Corticosteroids, anakinra, Infliximab, } \\
\text { immunosuppressive agent }\end{array}$ \\
\hline $\begin{array}{l}\text { Deficit of IL-1 receptor } \\
\text { antagonist }\end{array}$ & $\begin{array}{l}\text { Recessive } \\
\text { IL1RN (IL1 receptor } \\
\text { antagonist) }\end{array}$ & $\begin{array}{l}\text { Neonatal onset-multifocal osteomyelitis, } \\
\text { periostitis, neonatal onset-pustular rash }\end{array}$ & Anakinra \\
\hline Majeed's syndrome & $\begin{array}{l}\text { Recessive } \\
\text { LPIN2 (LPIN2) }\end{array}$ & $\begin{array}{l}\text { Recurrent multifocal osteomyelitis, } \\
\text { dyserythropoietic anemia, and chronic } \\
\text { dermatosis }\end{array}$ & $\begin{array}{l}\text { Corticosteroids, Bisphosphonates } \\
\text { TNF-inhibitor IL-1 antagonist } \\
\text { (anakinra) }\end{array}$ \\
\hline Blau's syndrome & $\begin{array}{l}\text { Dominant } \\
\text { NOD2/CARD15 (CARD15) }\end{array}$ & $\begin{array}{l}\text { Intermittent fever, granulomatous dermatitis, } \\
\text { polyarthritis, recurrent panuveitis }\end{array}$ & $\begin{array}{l}\text { Corticosteroids/TNF-a } \\
\text { inhibitor(infliximab), IL-1 antagonists }\end{array}$ \\
\hline
\end{tabular}

TNFRSF1A tumor necrosis factor receptor superfamily member 1A, NSAID non-steroidal anti-inflammatory drug, TNF tumor necrosis factor, NLRP3 nucleotide-binding oligomerization domain (NOD)-leucine-rich repeats LRR- and Pyrin domain-containing protein 3, PSTPIP1 proline-serine-threonine phosphatase interacting protein 1 , ILIRN interleukin 1 receptor antagonist, NOD2 nucleotide-binding oligomerization domain containing 2, CARD15 caspase recruitment domain-containing protein 15 
of destruction [9]. Although autoimmune diseases are still considered adaptive immunity-mediated disorders, there is increasing confirmation that innate immunity and inflammasomes are also included [10].

Autoimmune diseases were expressed to be rare but, through accurate epidemiological studies, have been shown to affect $3-5 \%$ of the population, with autoimmune thyroid disease and type 1 diabetes being the most common among other autoimmune diseases. Despite this, there are approximately a hundred distinct autoimmune diseases, various of which are organ-specific like primary biliary cirrhosis and some of which including multiple organs like systemic lupus erythematosus [11].

\section{Bridging autoinflammatory and autoimmune diseases The autoinflammatory-autoimmune diseases continuum} Autoimmune and autoinflammatory diseases have a lot of similarities in pathogenesis and clinical presentations, involving genetic predisposition and repeated systemic inflammatory attacks [12]. Autoinflammation was considered as a disorder of innate immunity (in clear difference to autoimmunity), where self-directed inflammation, induced by limited factors at sites that lead innate immune cells activated and target tissue injury will happen. For example, disturbed homeostasis of cytokine cascades (as in the periodic fever disorders), unusual bacterial sensing (as in Crohn's disease), and tissue microdamage predispose to local inflammation that is independent of adaptive immune responses. This led to the appearance of the immunological disease continuum classification of inflammation against self and too in the classical autoimmune diseases there is tolerance failure in the primary and secondary lymphoid organs with normal tissue being later exposed to an immunological storm [13].

Some diseases defined as classical autoimmune were then recognized to have a primary autoinflammatory beginning with secondary $\mathrm{T}$ cell-mediated target tissue autoimmune reactions that led to another category of diseases mediated between autoimmunity and autoinflammation also called (major histocompatibility complex MHC)-I associated disorders (Fig. 1) [14].

\section{The similarities between autoimmune and autoinflammatory diseases}

Autoinflammatory diseases are a set of monogenic and multifactorial (polygenic) disorders characterized by

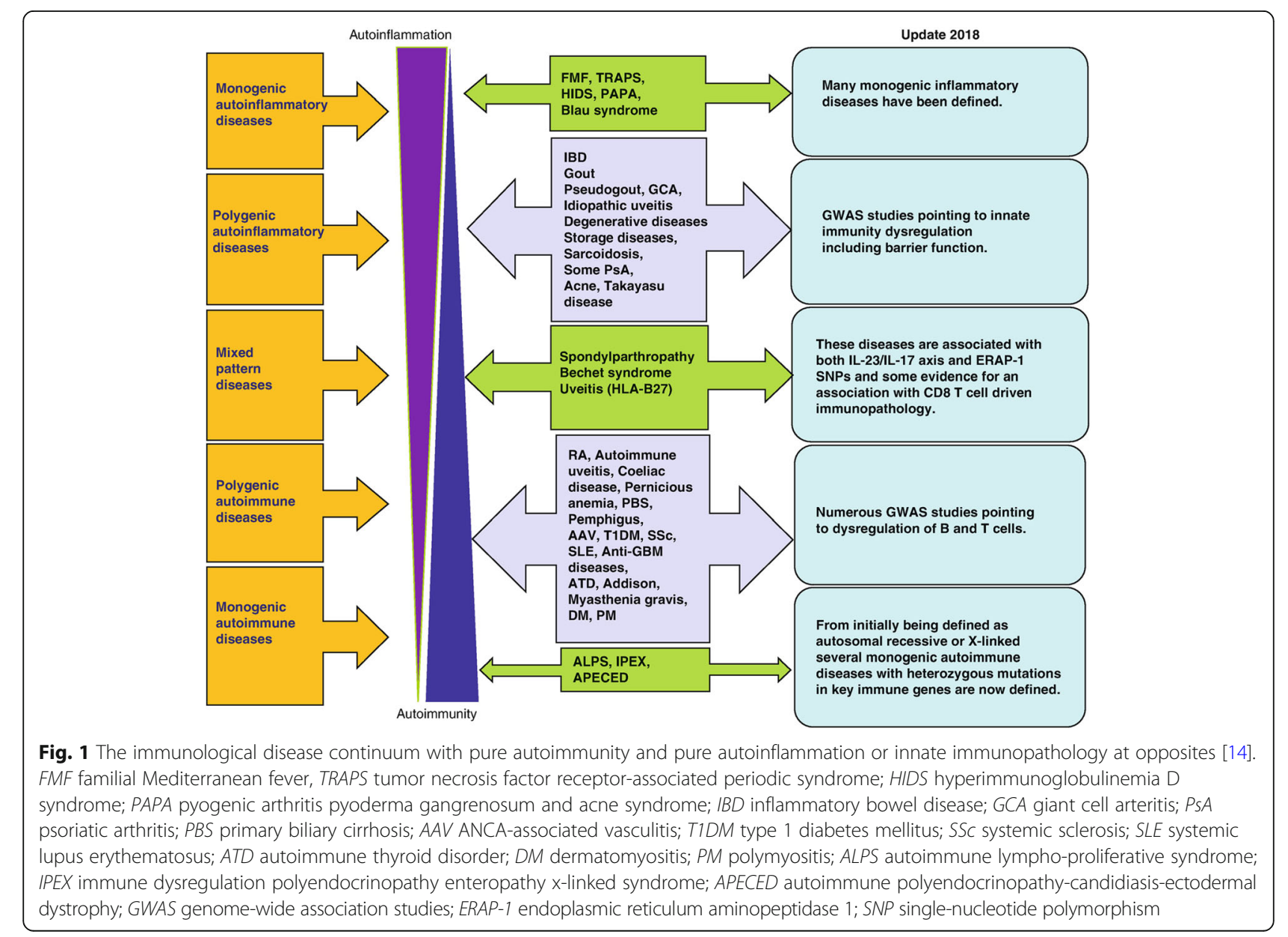


frequent inflammatory episodes whose heterogeneous symptoms are recurrently associated with fever. The significant pathogenetic mechanism in autoinflammation is direct and indirect dysregulation of inflammasomes, the multiprotein cytoplasmic complexes specific to innate immunity and inflammatory attacks. Although autoimmune diseases are known as disorders mediated by adaptive immunity, there is growing proof that innate immunity and inflammasomes are also tangled. It seems obvious that despite the contrast in the system primarily tangled, autoinflammatory, and autoimmune disease have common features as the activation against self, with subsequent systemic inflammation, and without any external causal factors trigger these attacks [15].

The association between autoimmunity and autoinflammation that can illuminate similarities between two systems is interleukin (IL-1 $\beta$ ), which is vital in linking the innate immune response due to nucleotide-binding oligomerization domain (NOD)-like receptor (NLR) activation and the adaptive immune responses of $\mathrm{T}$ and $\mathrm{B}$ cells. IL-1 has also a role in the activation of interferon $(\mathrm{IFN}-\gamma$ ) in memory $\mathrm{T}$ cells, $\mathrm{T}$ cell proliferation (which is also mediated by IL-2 and its receptor), increased B cell proliferation, and increased antibody synthesis, thus connecting the inflammasome-driven responses to the adaptive immune system in response to exogenous and endogenous signals [17].

Other evidence of the similarity between autoimmunity and autoinflammation regard nucleotide-binding oligomerization domain-containing protein 2 (NOD2), a member of a family of pattern recognition molecules with N-terminal caspase activation and recruitment domains (CARDS) that is also called the nucleotidebinding domain and leucine-rich repeat (LRR)-containing family. Autoinflammatory granulomatous diseases as Blau syndrome and early-onset sarcoidosis are result from NOD2 mutations in NACHT domains. At the same time, Crohn's disease results from polymorphisms in LRRs [18].

\section{The differences between autoinflammatory and autoimmune diseases}

Rheumatic diseases can be classified as autoimmune and autoinflammatory disorders. Although some autoinflammatory disorders can resemble autoimmune diseases and sometimes serve as a prelude to autoimmunity the underlying pathogenesis is mostly distinct. Autoinflammatory diseases are innate immune disorders triggered by exogenous or endogenous factors and are marked by systemic inflammation. By contrast, autoimmune diseases

Table 2 Summary of multifactorial autoinflammatory diseases [16]

\begin{tabular}{|c|c|c|}
\hline Multifactorial auto inflammatory syndromes & Prevalence & Main clinical features \\
\hline $\begin{array}{l}\text { Periodic fever, aphthous stomatitis, } \\
\text { pharyngitis, Adenitis syndrome }\end{array}$ & $<1 / 1,000,000$ & $\begin{array}{l}\text { Recurrent episodes of fever lasting 3-6 days, aphthosis, } \\
\text { cervical adenitis, pharyngitis }\end{array}$ \\
\hline Behcet's disease & 7.1 per 100,000 adults & $\begin{array}{l}\text { Recurrent oral aphthous ulcers, genital ulcers, eye manifestations, } \\
\text { venous thrombosis, arterial involvement, arthralgia/arthritis, } \\
\text { neurological manifestations, cardio-pulmonary involvement, } \\
\text { lymph and splenic enlargement, gastrointestinal symptoms, } \\
\text { genitourinary complications }\end{array}$ \\
\hline Crohn's disease & $\begin{array}{l}\text { 10-200 per 100,000 people in } \\
\text { North America and Europe }\end{array}$ & $\begin{array}{l}\text { Abdominal pain, diarrhea, rectal bleeding, weight loss, reduced } \\
\text { appetite, fever, fatigue, arthritis, uveitis, mouth sores, skin rash, } \\
\text { osteopenia/osteoporosis delay growth or sexual development } \\
\text { in children, hematological disorders, neurological involvement, } \\
\text { cardio-pulmonary manifestations, pancreatitis, genitourinary } \\
\text { involvement }\end{array}$ \\
\hline Still's disease & $\begin{array}{l}16 \text { to } 150 \text { cases per } 100,000 \\
\text { children worldwide }\end{array}$ & $\begin{array}{l}\text { Remitting fever, erythematous skin rash, serositis, arthritis, } \\
\text { lymphadenopathy, hepato-splenomegaly, anemia }\end{array}$ \\
\hline Adult-onset still disease & $\begin{array}{l}1.5 \text { cases per 100,000-1000,000 } \\
\text { people }\end{array}$ & $\begin{array}{l}\text { High spiking fever, arthralgia or arthritis, sore throat, } \\
\text { maculo-papular rash, lympho adenopathy, hepato- splenomegaly, } \\
\text { serositis }\end{array}$ \\
\hline Sweet's syndrome & $<1 / 1,000,000$ & $\begin{array}{l}\text { Fever, painful erythematous cutaneous nodules or plaques, } \\
\text { arthralgia, headache, hepato splenomegaly, eye manifestations, } \\
\text { central nervous system involvement, oral lesions, cardio-pulmonary } \\
\text { manifestations }\end{array}$ \\
\hline $\begin{array}{l}\text { Chronic recurrent multifocal } \\
\text { osteomyelitis syndrome }\end{array}$ & $<1 / 1,000,000$ & $\begin{array}{l}\text { Unifocal or multifocal, initially osteolytic, later hyperostotic and } \\
\text { sclerotic lesions mainly in the metaphyses of the long bones and } \\
\text { shoulder girdle }\end{array}$ \\
\hline $\begin{array}{l}\text { Synovitis, acne, pustulosis, } \\
\text { hyperostosis, osteitis syndrome }\end{array}$ & Unknown & $\begin{array}{l}\text { Bony lesions manifest as severe, recurrent, debilitating pain and } \\
\text { tenderness; cutaneous manifestations (palmo plantar pustulosis, } \\
\text { severe forms of acne and various forms of psoriasis, especially } \\
\text { pustular psoriasis) }\end{array}$ \\
\hline
\end{tabular}


are derived from abnormal responses to self-tissues mediated by both innate and adaptive immune cells; activation of autoreactive $\mathrm{T}$ and $\mathrm{B}$ cells ultimately causes the failure of immune tolerance, leading to chronic inflammation and local tissue destruction (Table 3) [19].

\section{Intermediate diseases between autoinflammation and autoimmunity: (major histocompatibility complex (MHC)-I associated disorders}

This group of clinically overlapping disorders termed the spondyloarthropathies (SPA) are mainly autoantibody negative and include psoriasis, psoriatic arthritis, Behcet's disease, ankylosing spondylitis, Crohn's disease, ulcerative colitis and uveitis, and other related disorders. Historically, these have been hard to know the relation that connects these diseases with autoinflammation and autoimmunity (Table 4). Several monogenic autoinflammatory syndromes appear to be closely related to these conditions, involving the deficiency of IL-36 receptor antagonist, Majeed's syndrome and pyogenic arthritis, pyoderma gangrenosum, and acne syndrome [20].

\section{Autoimmunity-autoinflammatory overlap}

The phenotype of both dystematic juvenile idiopathic arthritis (SJIA) in children and adult-onset still disease (AOSD) is viewed as part of the autoinflammatory spectrum. This is reinforced by evidence for an IL-1 transcriptional signature and responses to anti-IL-1 treatment. Poorly well-defined, or what was historically called "atypical AOSD", is now considered as an autoinflammatory or unclassified systemic autoinflammatory disease. While SJIA has a rare monogenic variant documented in Arab populations, the typical cases of AOSD have a major histocompatibility complex-II association that related to autoimmunity, this can prove the presence of overlap between autoinflammation and autoimmunity [21].

\section{The systemic lupus erythematosus (SLE) (the best example of bridging between autoinflammatory and autoimmune diseases)}

The immunological disease continuum set Systemic lupus erythematosus toward the side of autoimmunity but even in 2006, it was known that soluble innate immunity, or the complement system, was connected to various SLE features with a decrease in C2, 3, and c4 that lead to the presence of SLE phenotypes (Fig. 2). Hence, SLE is placed to the side of the adaptive boundary or self-directed inflammation. But innate immunity might also be involved. Despite, beyond complement, Mendelian diseases collectively called "the interferonopathies", due to impaired metabolism of self-nucleic acids, with elevated levels of type I IFN also lead to autoantibody associated SLE [22].

\section{Clinical approach to differentiate autoinflammation from autoimmunity: \\ Clinical investigations}

The approach to differentiate autoinflammation from autoimmunity starts with good medical and family history, physical examination, laboratory tests involving complete blood count, level of complement and

Table 3 The differences between autoinflammatory and autoimmune diseases

\begin{tabular}{|c|c|c|}
\hline Categories & Autoinflammatory diseases & Autoimmune diseases \\
\hline $\begin{array}{l}\text { Factors determining disease } \\
\text { manifestations }\end{array}$ & $\begin{array}{l}\text { Innate immune activation } \\
\text { Local tissue factors at disease-prone sites, } \\
\text { including tissue trauma, necrosis, mechanical } \\
\text { factors, bacteria or their constituent molecules }\end{array}$ & $\begin{array}{l}\text { Adaptive immune activation } \\
\text { Clinical disease expression determined by events } \\
\text { taking place in primary lymphoid tissues, including } \\
\text { bone marrow, the thymus, lymph nodes and spleen }\end{array}$ \\
\hline Key theory relating to disease expression & $\begin{array}{l}\text { Various danger signals with tissue-specific } \\
\text { factors determining disease localization }\end{array}$ & $\begin{array}{l}\text { Breakdown of immunological tolerance and } \\
\text { aberrant self-non-self-discrimination }\end{array}$ \\
\hline Immunological basis & $\begin{array}{l}\text { Genetically related to perturbations of innate } \\
\text { immune function, including proinflammatory } \\
\text { cytokine signaling/bacterial sensing/local } \\
\text { tissue abnormalities }\end{array}$ & $\begin{array}{l}\text { Acquired immune perturbation is key to disease } \\
\text { expression: infiltration of Rheumatoid arthritis synovium, } \\
\text { proliferation of macrophage-like synoviocytes and } \\
\text { fibroblast-like synoviocytes, and infiltration of } \\
\text { inflammatory cells, including B and T lymphocytes, } \\
\text { and dendritic cells }\end{array}$ \\
\hline Cellular basis & $\begin{array}{l}\text { Expression determined by cells of the innate } \\
\text { immune system, including neutrophils and } \\
\text { macrophages or non-immune cells }\end{array}$ & $\begin{array}{l}\text { An antigen-independent induction phase-expression } \\
\text { is mainly determined by factors affecting B- and } \\
T \text { cell activity }\end{array}$ \\
\hline Genetic basis & Cytokine and sensing bacterial pathways & MHC class II association and adaptive response gene \\
\hline Therapy & Anti-cytokine(II-1, IL-6, TNF ) & Anti-B and $T$ cell \\
\hline Classification & $\begin{array}{l}\text { Monogenic: hereditary periodic fever } \\
\text { Polygenic: as Crohn's diseases, } \\
\text { spondyloarthropathies }\end{array}$ & $\begin{array}{l}\text { Monogenic: immune dysregulation polyendocrinopathy } \\
\text { enteropathy x-linked syndrome } \\
\text { Polygenic: rheumatoid arthritis, systematic lupus } \\
\text { erythematosus }\end{array}$ \\
\hline
\end{tabular}


Table 4 The main differences between autoimmune, monogenic autoinflammatory disorders and (major histocompatibility complex)-I associated disorders [20]

\begin{tabular}{llll}
\hline Variable & Autoimmune diseases & $\begin{array}{l}\text { Mono genic autoinflammatory } \\
\text { diseases }\end{array}$ & MHC-1- opathy \\
\hline Epidemiology & Common & Rare & Rare \\
Gender & Female predominance & None & Diseases dependent \\
Age of onset & Diseases dependent & Generally young & Generally young \\
Primary site of disease & Lymphoid organ & Tissue target & Tissue target \\
Immunopathogenesis & Predominant Adaptive & $\begin{array}{l}\text { Predominant Innate system } \\
\text { impairment }\end{array}$ & $\begin{array}{l}\text { Innate system dysregulation with secondary } \\
\text { MHC-I /ERAP-1 associated IL23/17 cytokine } \\
\text { axis dysregulation }\end{array}$ \\
Main cellular involvement & B and T cells & Neutrophils, Macrophages & $\begin{array}{l}\text { Myeloid cell } \\
\text { Innate lymphocyte }\end{array}$ \\
CD8 T cell & MHC-1 ERAP-1/2 IL-23/IL-17 axis \\
Genetic predisposition & MHC-II associations & Cytokine and bacterial sensing & pathways \\
Therapy & B cell depletion DMARDs & Anti-cytokines as (anti-IL-1\} & $\begin{array}{l}\text { Anti-cytokines IL-23/L-17 but not B cell } \\
\text { depletion }\end{array}$ \\
Natural history & Progressive & Recurrent & Waxing and waning \\
\hline
\end{tabular}

MHC major histocompatibility complex, IL interleukin, ERAP-1 endoplasmic reticulum aminopeptidase 1, DMARDs disease-modifying anti-rheumatic drugs

immunoglobulin in serum, general biochemistry, inflammatory biomarkers, and relevant autoantibodies. By the time autoinflammation is considered as a diagnosis, most patients will already have had a total workup involving assessment of infectious disease with blood cultures, viral, and bacteriological serologic studies [23].

\section{Molecular investigations}

The best test for the diagnosis of autoinflammatory disorders is an initial screen of genes known to be associated with monogenic autoinflammatory diseases.
Patients tend to be sporadic rather than familial in hospitals. The difficulty of the genetic analysis is elevating, for example, the recognition that heterozygous mutations in the MEFV gene may be connected to Familial Mediterranean fever or other inflammatory phenotypes. While homozygous mutations are needed for autoimmune or autoinflammatory phenotypes in animal models, e.g., for CTLA4 or TNFAIP3, heterozygous mutations are associated with the presence of a Behcet's disease-like phenotype. Unpopular types of NOD2 or TNFR1 are not infrequently present in patients with

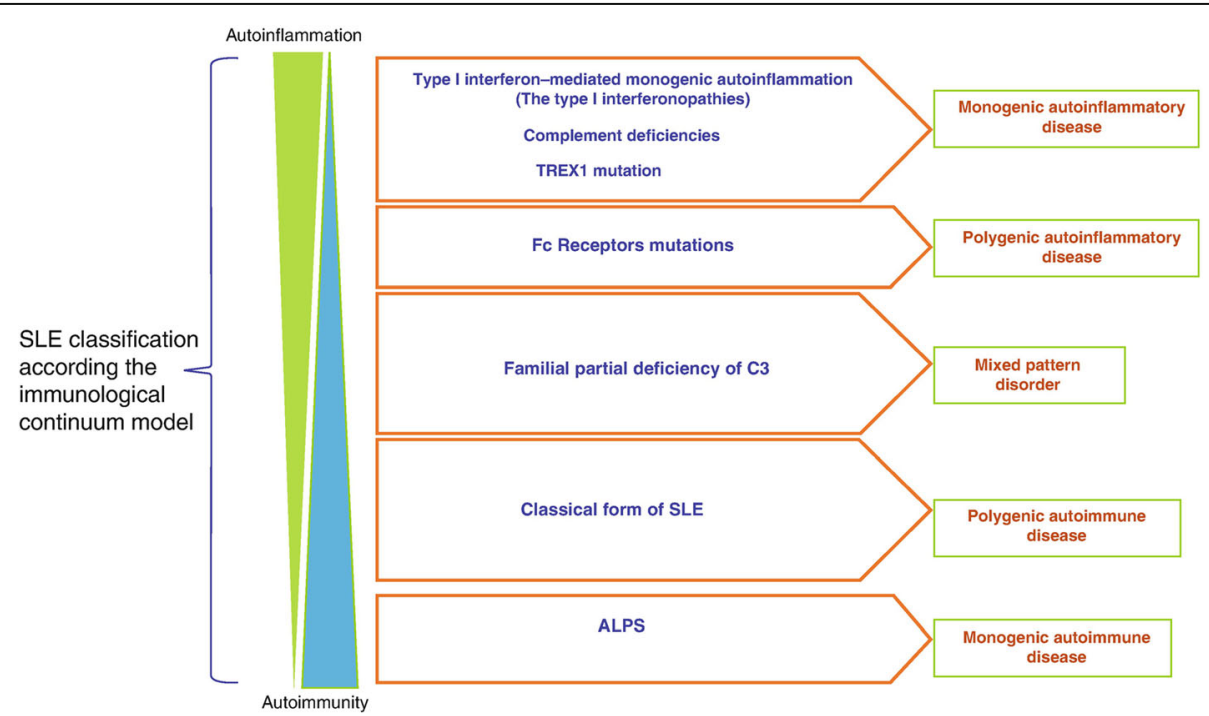

Fig. 2 SLE is a one of the best examples in which the immunological continuum model can be applied showing the diversity of clinical manifestation according the involvement of different genetic and immune system components. SLE systemic lupus erythematosus; ALPS autoimmune lympho-proliferative syndrome; TREX1 three prime repair exonuclease 1 
autoinflammatory disease clinics and their full meaning waits to be illuminated [24].

\section{Complications of autoinflammatory disorders against autoimmune disorders}

The intensity of autoinflammatory disorders ranges from very mild disease to dangerous forms resulting in elevation of rates of mortality. Patients can present with poorly defined autoinflammatory-driven shock and circulatory collapse which similar to septicemia. This really may be part of the autoinflammatory disease spectrum under the coverage of (macrophage activation syndrome) MAS. Indeed, MAS and severe sepsis resemble each other in the clinical, laboratory, pathological characters, involving an increase in ferritin level, various cytopenia, hepatic impairment with an elevation of liver enzymes, in particular, coagulopathy with a disseminated intravascular coagulation and tissue hemophagocytosis. In differences to autoinflammatory disorders, serious autoimmune diseases tend to exhibit a predominant attack of a single organ system and absence of the severe constitutional features with some exceptions involving dangerous antiphospholipid syndrome, pulmonary involvement in antiglomerular basement membrane syndrome, or severe autoimmune nephritis [25].

\section{Therapeutic implications of autoinflammation and autoimmunity}

Not only the autoimmunity and autoinflammation had common anatomical and genetic features but their useful therapeutic manipulation further represents immune pathogenesis and proper disease categorization. The emerging therapeutic results show an overarching concept but there are some therapeutic exceptions in these groups. For example, molecules that selectively target B cells (primarily anti-CD20 therapy with rituximab) are used in many of the classical autoantibody associated disorders. On the other side, predominantly

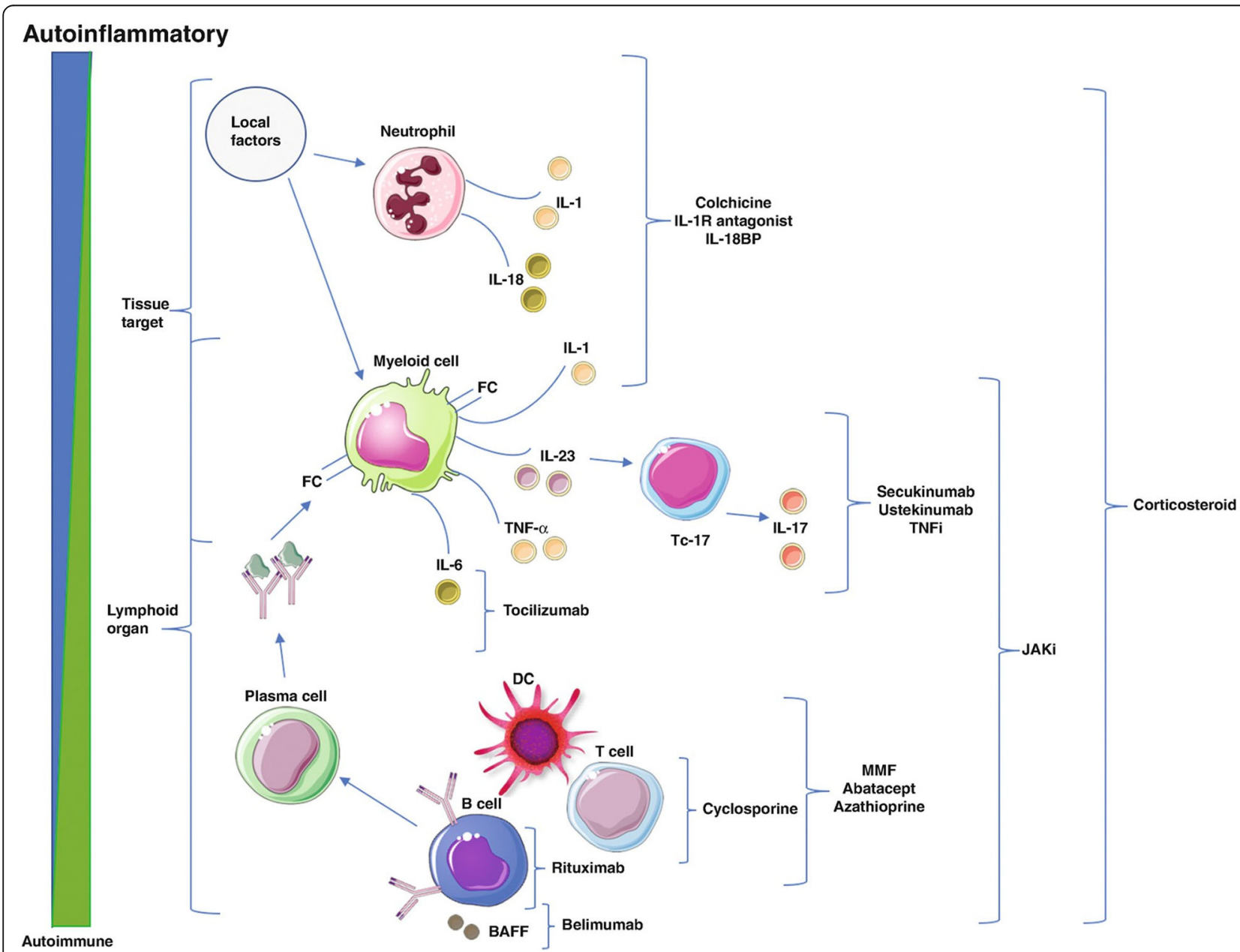

Fig. 3 Autoimmunity and autoinflammation classification is reflected in differential therapeutic targeting. MMF mycophenolate mofetil; BAFF B cell activating factor; IL interleukin; IL-1R IL-1 receptor; IL-18BP IL-18 binding protein; TNF tumor necrosis factor; TNFI TNF inhibitor; JAKI Janus kinase inhibitor 
autoinflammatory disorders often represent good results for anti-IL-1 therapy [26].

The non-autoantibody-mediated SpA-associated disorders commonly represent very good results to cytokine blockers and anti-TNFs. The "intermediate diseases" or "MHC-I-opathy" disorders express good results to therapies that block the IL-23/17 axis likely representing how local tissue factors ultimately arrange the so-called type 17 innate and adaptive lymphocytes to drive IL-17associated pathology. Small molecules antagonize conventional $\mathrm{T}$ cells action over a large range of inflammatory diseases, but commonly less well than cytokine blockers. Steroids work through the entire spectrum of inflammatory disorders likely reflecting a lot of results on the immune system. Finally, the heterogeneity and difficulty of the immune system need to be well-known, reflecting the fact that some cytokine blockers, especially IL-6 antagonist, is useful in several adaptive immune disorders as well as innate/autoinflammatory disorders (Fig. 3) [14].

\section{Conclusions}

Autoinflammatory and autoimmune disorders are marked by aberrant changes in innate and adaptive immunity that may lead to initial inflammatory action to an organ specific damage. These diseases have heterogeneity in terms of affected organs and clinical phenotypes. Despite the differences in etiology and phenotypic variations, they have common genetic associations, treatment responses, and clinical presentations, consequently, the presence of some similarities and differences between autoimmune and autoinflammatory disorders indicates variable degrees of bridging and overlapping between them.

\section{Abbreviations}

NOD: Nucleotide-binding oligomerization domain; NLR: Nucleotide-binding oligomerization domain (NOD)-like receptor; IL-1: Interleukin; IFN: Interferon; LRR: Leucine-rich repeat; MHC: Major histocompatibility complex; SPA: Spondylo arthropathies; SJIA: Systematic juvenile idiopathic arthritis; AOSD: Adult onset still disease; SLE: Systemic lupus erythematosus; CTLA4: Cytotoxic T-lymphocyte antigen 4; TNFAIP3: Tumor necrosis factor alpha-induced protein 3; MAS: Macrophage activation syndrome; TNF: Tumor necrosis factor; TNFR1: Tumor necrosis factor receptor 1

\section{Acknowledgements}

To all mentioned authors.

\section{Authors' contributions}

EE contributed to writing main text and conclusion of the manuscript. EZ contributed to tables and figure writing. SS gave the idea of the review and design of all parts of the manuscript. EH shared in all parts of the manuscript. All authors read and approved the final manuscript.

\section{Funding}

No funding

\section{Availability of data and materials}

The datasets used during this review are available from the corresponding author.

\section{Declarations}

Ethics approval and consent to participate

Not applicable

\section{Consent for publication}

Not applicable

\section{Competing interests}

The authors declare that they have no competing interests.

\section{Author details}

${ }^{1}$ Rheumatology and Immunology Unit, Department of Internal Medicine, Faculty of Medicine, Menoufia University, Shebin El-Kom, Egypt. ${ }^{2}$ Research Committee, Faulty of Medicine, Menoufia University, Shebin El-Kom, Egypt.

Received: 26 December 2020 Accepted: 16 March 2021

Published online: 29 March 2021

\section{References}

1. Caso F, Costa L, Nucera V, Barilaro G, Masala IF, Talotta R, Caso P, Scarpa R, Sarzi-Puttini P, Atzeni F (2018) From autoinflammation to autoimmunity: old and recent findings. Clin Rheumatol. 37(9):2305-2321. https://doi.org/10.1 007/s10067-018-4209-9

2. Ben-Chetrit E, Gattorno M, Gul A, Kastner DL, Lachmann HJ, Touitou I, Ruperto N, Paediatric Rheumatology International Trials Organisation (PRIN TO) and the AIDs Delphi study participants (2018) Consensus proposal for taxonomy and definition of the autoinflammatory diseases (AIDs): a Delphi study. Ann Rheum Dis. 77(11):1558-1565. https://doi.org/10.1136/a nnrheumdis-2017-212515

3. De Luca F, Shoenfeld $Y$ (2019) The microbiome in autoimmune diseases. Clin Exp Immunol. 195(1):74-85. https://doi.org/10.1111/cei.13158

4. Van Kempen TS, Wenink MH, Leijten EF, Radstake TR, Boes M (2015) Perception of self: distinguishing autoimmunity from autoinflammation. Nat Rev Rheumatol. 11(8):483-492. https://doi.org/10.1038/nrrheum.2015.60

5. Doria A, Zen M, Bettio S, Gatto M, Bassi N, Nalotto L, Ghirardello A, laccarino L, Punzi L (2012) Autoinflammation and autoimmunity: bridging the divide. Autoimmun Rev. 12(1):22-30. https://doi.org/10.1016/j.autrev.2012.07.018

6. Havnaer A, Han G (2019) Autoinflammatory disorders: a review and update on pathogenesis and treatment. Am J Clin Dermatol 1:1-26

7. Broderick L (2019) Hereditary autoinflammatory disorders: recognition and treatment. Immunol Allergy Clin. 39(1):13-29. https://doi.org/10.1016/j.iac.2 018.08 .004

8. Davidson A and Diamond B. General features of autoimmune disease. InThe autoimmune diseases 2020(pp. 17-44).

9. Amaya-Uribe L, Rojas M, Azizi G, Anaya JM, Gershwin ME (2019) Primary immunodeficiency and autoimmunity: a comprehensive review. J Autoimmun. 99:52-72. https://doi.org/10.1016/j.jaut.2019.01.011

10. Zhang P, Lu Q (2018) Genetic and epigenetic influences on the loss of tolerance in autoimmunity. Cell Mol Immunol. 15(6):575-585. https://doi. org/10.1038/cmi.2017.137

11. Parikh NS, Merkler AE, ladecola C (2020) Inflammation, autoimmunity, infection, and stroke: epidemiology and lessons from therapeutic intervention. Stroke. 51(3):711-718. https://doi.org/10.1161/STROKEAHA.119. 024157

12. Zen $M$, Gatto M, Domeneghetti M, Palma L, Borella E, laccarino $L$ et al Clinical guidelines and definitions of autoinflammatory diseases: contrasts and comparisons with autoimmunity - a comprehensive review. Clin Rev Allergy Immunol. 2013;45(2):227-235 doi: https://doi.org/10.1007/s12016013-8355-1.

13. Goldbach-Mansky $R$ and de Jesus AA. Classification of genetically defined autoinflammatory diseases. InTextbook of Autoinflammation 2019 (pp. 167-201).

14. McGonagle D and Watad A. Autoinflammation and Autoimmunity. In Textbook of Autoinflammation 2019 (pp. 693-710).

15. Georgin-Lavialle S, Fayand A, Rodrigues F, Bachmeyer C, Savey L, Grateau G et al (2019) Autoinflammatory diseases: State of the art. La Presse Médicale. 48(1):e25-e48. https://doi.org/10.1016/j.lpm.2018.12.003

16. Berg S, Wekell $P$, Fasth A, Hawkins PN and Lachmann H. Autoinflammatory disorders. InPrimary Immunodeficiency Diseases 2017 (pp. 393-435).

17. Bendtzen K (2011) Innate immunity, autoimmunity and autoinflammation. Ugeskrift for laeger. 173(38):2337-2340 
18. Yao Q, Shen B (2017) A systematic analysis of treatment and outcomes of NOD2-associated autoinflammatory disease. Am J Med. 130(3):365-e13

19. Krainer J, Siebenhandl S, Weinhäusel A (2020) Systemic autoinflammatory diseases. J Autoimmun. 109:102421. https://doi.org/1 0.1016/j.jaut.2020.102421

20. Sharip A, Kunz J (2020) Understanding the Pathogenesis of Spondyloarthritis. Biomolecules. 10(10):1461. https://doi.org/10.3390/biom1 0101461

21. Arakelyan A, Nersisyan L, Poghosyan D, Khondkaryan L, Hakobyan A, LöfflerWirth $H$, Melanitou E, Binder H (2017) Autoimmunity and autoinflammation: a systems view on signaling pathway dysregulation profiles. Plos One. 12(11):e0187572. https://doi.org/10.1371/journal.pone.0187572

22. Hedrich CM, Surace AE (2019) The role of epigenetics in autoimmune/ inflammatory disease. Front Immunol. 10:1525

23. Ceccherini I, Rusmini M and Arostegui Jl. Genetic Aspects of Investigating and Understanding Autoinflammation. InTextbook of Autoinflammation 2019 (pp. 19-48).

24. Moghaddas F, Masters SL (2018) The classification, genetic diagnosis and modelling of monogenic autoinflammatory disorders. Clin Sci. 132(17):19011924. https://doi.org/10.1042/CS20171498

25. Watad A, Bragazzi NL, McGonagle D, Adawi M, Bridgewood C, Damiani G et al (2019) Autoimmune/inflammatory syndrome induced by adjuvants (ASIA) demonstrates distinct autoimmune and autoinflammatory disease associations according to the adjuvant subtype: Insights from an analysis of 500 cases. Clin Immunol 203:1-8

26. Arts RJ, Joosten LA, Netea MG (2018) The potential role of trained immunity in autoimmune and autoinflammatory disorders. Front Immunol. 9:298. https://doi.org/10.3389/fimmu.2018.00298

\section{Publisher's Note}

Springer Nature remains neutral with regard to jurisdictional claims in published maps and institutional affiliations.

\section{Submit your manuscript to a SpringerOpen ${ }^{\circ}$ journal and benefit from:}

- Convenient online submission

- Rigorous peer review

- Open access: articles freely available online

- High visibility within the field

- Retaining the copyright to your article

Submit your next manuscript at $\boldsymbol{\nabla}$ springeropen.com 